\title{
PENGARUH STRATEGI HARGA TERHADAP KEPUTUSAN PEMBELIAN KONSUMEN DI TOKO KAKIKU BIAK
}

\author{
Sri Handayani ${ }^{1}$ \\ shanday@gmail.com \\ Krismiyati ${ }^{2}$ \\ Krisyati88@gmail.com \\ Novidatul Husna ${ }^{3}$

\begin{abstract}
1 Dosen Jurusan Administrasi Publik Fakultas IImu Administrasi Publik Institut IImu Sosial dan IImu Politik Yapis Biak,
2 Dosen Jurusan Administrasi Publik Fakultas IImu Administrasi Publik Institut IImu Sosial dan IImu Politik Yapis Biak,

${ }^{3}$ Mahasiswa Jurusan Administrasi Publik Fakultas IImu Administrasi Publik Institut IImu Sosial dan IImu Politik Yapis Biak
\end{abstract}

\section{Abstraksi:}

Penelitian ini akan menjelaskan mengenai hubungan strategi harga terhadap keputusan pembelian konsumen di Toko KAKIKU Biak dan hubungan yang signifikan strategi harga dengan keputusan pembelian konsumen di Toko KAKIKU Biak.. lokasi penelitian dilakukan pada toko KAKIKU yang beralamat di Jalan Bosnik Raya, Biak Numfor. Penelitian ini menggunakan jenis penelitian kuantitatif. pada filsafat positivisme, digunakan untuk meneliti pada populasi atau sampel tertentu, teknik pengambilan sampel pada umumnya dilakukan random, pengumpulan data menggunakan instrumen penelitian, analisis data bersifat kuantitatif/statistik dengan tujuan untuk menguji hipotesis yang telah ditetapkan. Hasil penelitian menunjukkan. Hasil uji koefisien

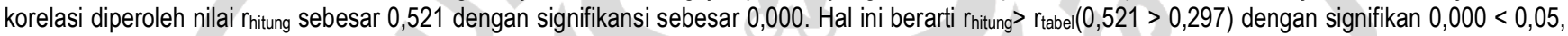
maka dapat disimpulkan bahwa variabel strategi harga mempunyai hubungan yang signifikan terhadap keputusan pembelian konsumen. besarnya nilai $r$ square adalah 0,272. Strategi harga berpengaruh signifikan terhadap keputusan pembelian konsumen di Toko KAKIKU Biak. Hal ini dinyatakan berdasarkan uji t, strategi harga berpengaruh signifikan terhadap keputusan pembelian konsumen. Hal ini menyatakan bahwa Toko KAKIKU Biak dengan memperhatikan strategi penjualan menegenai harga seperti keterjangkauan harga, keseuaian harga dengan kualitas , daya saing harga dan kesesuaian harga dengan manfaat maka akan semakin tinggi pula dalam menentukan keputusan pembelian konsumen, sebab konsumen dapat menentukan pembelian suatu produk sesuai kebutuhan dan keinginannya.

Kat a Kunci : Strategi, Penjualan, Konsumen.

\section{PENDAHULUAN}

\section{A. Latar Belakang}

Fashion di Indonesia telah berkembang dengan baik. Dalam perkembangannya, fashion terus mengalami perubahan seiring dengan gaya hidup masyarakat. Fashion yang dikenakan seseorang dapat menunjukkan identitasnya bagi pemakainya. Oleh karena itu, wajar banyak orang yang sangat peduli dengan penampilan. Hal tersebut menjadikan salah satu alasan fashion sangat penting dalam perkembangan kehidupan manusia. Urusan penampilan inilah yang telah lama menjadi trend dan budaya yang harus diikuti agar seseorang tidak ketinggalan zaman.

Ada banyak aneka perlengkapan fashion yang dapat kita jumpai. Salah satunya produk sepatu yang berfungsi sebagai alas kaki yang sering digunakan sehari-hari. Saat ini sepatu menjadi fashion yang banyak disukai. Sepatu telah menjadi bagian penting dalam dunia fashion dan telah mengalami peralihan fungsi yang dapat melengkapi penampilan seseorang. Hal ini yang membuat industri sepatu di Indonesia semakin berkembang.

Dari hari ke hari, semakin banyak para pelaku bisnis yang menjual beragam model sepatu. Seperti sepatu sekolah, sepatu formal, sepatu olahraga dan lain-lain. Hal ini membuat konsumen mempunyai banyak pilihan untuk menggunakan produk yang ditawarkan oleh para penjual. Semakin banyak produk yang ditawarkan maka semakin ketat pula persaingan dalam dunia bisnis. Persaingan yang semakin ketat membuat para pelaku bisnis diharuskan mampu menciptakan produkproduk yang lebih unggul untuk memenuhi kebutuhan dan keinginan konsumen. Untuk mengatasi hal tersebut, pelaku bisnis harus memiliki strategi pemasaran yang kuat dalam bersaing. 
Persaingan dunia bisnis juga dialami oleh toko KAKIKU Mandiri Biak yang merupakan sebuah toko yang menyediakan beragam sepatu dan sandal serta beberapa aksesories yang berlokasi di Jalan Bosnik Raya, Kabupaten Biak Numfor. Toko KAKIKU Biak mengalami persaingan ketat dengan toko lain yang sejenisnya. Maka toko KAKIKU Biak harus lebih berupaya mengatur pemasaran sehingga dapat merebut pangsa pasar. Agar dapat dikenal luas oleh masyarakat dan meningkatkan penjualan. Adapun data penjualan toko KAKIKU sebagai berikut:

Tabel 1. Data Penjualan KAKIKU Biak Bulan Juli - Desember 2019

\begin{tabular}{|c|l|c|c|}
\hline No. & \multicolumn{1}{|c|}{ Bulan } & Jumlah Penjualan(Unit) & Omset (Rp) \\
\hline 1 & Juli & 1.503 & 196.191 .962 \\
\hline 2 & Agustus & 825 & 123.876 .981 \\
\hline 3 & September & 609 & 89.776 .824 \\
\hline 4 & Oktober & 580 & 78.890 .732 \\
\hline 5 & November & 549 & 76.553 .964 \\
\hline 6 & Desember & 1.007 & 126.071 .472 \\
\hline
\end{tabular}

Sumber data: KAKIKU Biak, 2019

Dari tabel di atas dapat dilihat tingkat penjualan toko KAKIKU Biak dari bulan ke bulan yang tidak stabil. Toko KAKIKU memperoleh omset atau pendapatan penjualan yang paling terbesar di bulan Juli 2019 sebesar Rp 196.191.962. Kemudian dari bulan Juli hingga November 2019 berturut-turut mengalami penurunan. Ini dikarenakan semakin ketatnya persaingan antar toko sejenisnya. Tetapi pada bulan Desember 2019 mengalami peningkatan sebesar Rp 126.071.472. Peningkatan tersebut dikarenakan pada bulan Desember ada event Hari Raya Natal dan Tahun Baru yang dimana pada event-event seperti itu toko KAKIKU memberikan sejumlah diskon yang dapat meningkatkan penjualannya.

\section{B. Tujuan Penelitian}

Berdasarkan latar belakang yang dikemukakan di atas, maka dirumuskan permasalahan penelitian sebagai berikut:

1. Berapa besar hubungan strategi harga terhadap keputusan pembelian konsumen di Toko KAKIKU Biak?

2. Berapa besar sumbangan strategi harga terhadap keputusan pembelian konsumen di Toko KAKIKU Biak?

3. Apakah ada hubungan yang signifikan strategi harga dengan keputusan pembelian konsumen di Toko KAKIKU Biak?

\section{LANDASAN TEORI}

\section{A. Kajian Teori}

\section{Pemasaran}

Kotler dan Amstrong (2015:76)mengatakan bahwa Pengertian Marketing, dapat dilihat dari 2 sudut pandang, Pengertian dari sudut pandang Societal (masyarakat) menunjukan peranan marketing dalam masyarakat. Sedangkan menurut pandangan marketer, marketing berperan untuk menyampaikan standar hidup yang lebih tinggi bagi masyarakat.

"Marketing is a societal process by which individual and groups obtain what they and want through creating, offering, and freely exchanging products and services of value with others"

Artinya marketing adalah proses dimana seseorang atau kelompok dapat memenuhi need dan want melalui penciptaan, penawaran dan pertukaran barang dan jasa. Dari pengertian tersebut dapat disimpulkan bahwa pemasaran adalah segala kegiatan usaha yang meliputi kegiatan produksi, distribusi, penawaran dan pertukaran barang atau jasa

\section{a. Bauran Pemasaran (Marketing Mix)}

Berikut ini unsur-unsur bauran pemasaran atau marketing mix menurut Kotler dan Amstrong (2012:25) yaitu:

1) Product (Produk) 
Produk adalah suatu yang dapat ditawarkan ke pasar untuk mendapatkan perhatian, agar produk yang dijual mau dibeli, digunakan atau dikonsumsi yang dapat memenuhi suatu kegiatan atau kebutuhan dari konsumen.

2) Price (Harga)

Harga adalah sejumlah nilai yang ditukarkan konsumen dengan manfaat dari memiliki atau menggunakan produk atau jasa yang nilainya ditetapkan oleh pembeli dan penjual melalui tawar menawar, atau ditetapkan oleh penjual untuk satu harga yang sama terhadap semua pembeli.

3) Place (Tempat)

Tempat sebagai saluran distribusi yang ditujukan untuk mencapai target konsumen. Sistem distribusi ini mencakup lokasi, transportasi, pengudangan, dan sebagainya.

4) Promotion/promosi

Promosi berarti aktivitass yang menyampaikan manfaat produk dan membujuk pelanggan membelinya.

Marketing Mix adalah kombinasi dari variabel atau kegiatan yang merupakan inti dari sistem pemasaran yaitu produk, harga, promosi, dan distribusi. Dengan kata lain marketing mix adalah kumpulan dari variabel yang dapat digunakan oleh perusahaan untuk dapat mempengaruhi tanggapan konsumen (Sumarmi dan Soeprihanto, 2010:274).

\section{Harga}

Value merupakan nilai suatu produk untuk ditukarkan dengan produk lain. Nilai ini dapat dilihat dalam situasi barter yaitu pertukaran antara barang dengan barang. Sekarang ini tidak melakukan barter lagi, akan tetapi sudah menggunakan uang sebagai ukuran yang disebut harga. Harga adalah nilai suatu barang yang dinyatakan dengan uang (Alma, 2004:171).

\section{a. Peranan Harga dalam Pengambilan Keputusan Pembelian}

Menurut Tjiptono (2008:152) harga memiliki dua peranan utama dalam proses pengambilan keputusan pembelian yaitu :

1) Peranan alokasi dari harga

Fungsi harga dalam membantu para pembeli untuk memutuskan cara memperoleh manfaat atau utilitas tertinggi yang diharapkan berdasarkan daya belinya.

2) Peranan informasi dari harga

Fungsi harga dalam "mendidik" konsumen mengenaik faktor-faktor produk, seperti kualitas. Hal ini terutama bermanfaat dalam situasi dimana pembeli mengalami kesulitan untuk menilai faktor produk atau manfaatnya secara objektif.

\section{Penetapan Harga}

\section{a. Strategi Penetapan Harga}

Strategi penetapan harga merupakan proses perusahan dalam mengklasifikasikan dan menggolongkan produk yang dihasilkan apakah produk baru atau produk yang telah beredar.

\section{1) Produk Baru}

Dalam pengenalan produk baru perlu penetapan strategi harga. Berikut ini merupakan penetapan harga yang efektif terdapat 2 alternatif yaitu :

a) Harga Mengapung (Skimming price)

Harga mengapung adalah memberikan harga yang tinggi agar dapat menutupi biaya dan sekaligus menghasilkan laba maksimum atau dengan kata lain dalam hal ini perusahaan mampu menyakinkan pelanggan bahwa produknya memiliki perbedaan dengan produk sejenis yang dimiliki pesaing. Harga mengapung disebut juga dengan pendekatan skimming, pendekatan ini sangat efektif apabila terdapat perbedaan harga atas aspek tertentu dan pesaing relative sedikit. Selain itu, pendekatan skimming bermanfaat sebagai pembatas atas permintaan suatu produk sampai perusahaan merassa siap kembali untuk melakukan produksi secara massal.

b) Harga Penetrasi 
Harga penetrasi adalah memberikan harga lebih rendah agar tercipta pangsa pasar permintaan, umumnya diterapkan pada kondisi pasar yang tidak terfragmentasi ke dalam aspek berbeda produk dan itu tidak memiliki nilai simbolis yang tinggi.

\section{2) Produk yang telah beredar}

Strategi penetapan harga pada produk yang telah beredar di masyarakat umumnya tidak lepas dari posisi produk dalam siklus produk.

\section{Perilaku Konsumen}

Perilaku konsumen menurut J. Paul Peter dan Jerry C. Oslo dalam Tjiptono (2002:65) adalah interaksi dinamis antara pengaruh kognitis perilaku dan kejadian di sekitar kota dimana manusia melakukan aspek pertukaran dalam hidup mereka. Sedangkan perilaku konsumen menurut Engel (1994:95) adalah sebagai tindakan yang langsung terlibat dalam mendapatkan, mengkonsumsi dan menghabiskan produk dan jasa termasuk proses keputusan yang mendahului dan menyusul tindakan ini.

\section{Keputusan Pembelian}

Menurut Tjiptono (2009), keputusan pembelian adalah sebuah proses dimana konsumen mengenal masalahnya, mencari informasi mengenai produk atau merek tertentu dan mengevaluasi seberapa baik masing-masing alternatif tersebut dapat memecahkan masalahnya, yang kemudian mengarah kepada keputusan pembelian.

\section{a. Peran dalam Pengambilan Keputusan Pembelian}

Kotler dalam Tjiptono (2008:20) berpendapat bahwa keputusan pembelian konsumen seringkali ada lebih dari dua pihak dari proses pertukaran atau pemeblian. Umumnya ada lima macam peran yang dapat dilakukan seseorang.. Kelima peran tersebut meliputi:

1) Pemrakarsa adalah orang yang pertama kali menyarankan membeli suatu produk atau jasa.

2) Pembeli pengaruh adalah orang yang pandangan atau nasehatnya memberik bobot dalam pengambilan keputusan akhir.

3) Pengambil keputusan adalah orang yang sangat menentukan sebagian atau keseluruhan keputusan pembelian, apakah pembeli, apa yang dibeli, kapan hendak membeli, bagaimana cara membeli, dan dimana akan membeli.

4) Pembeli adalah orang yang melakukan pembelian nyata.

5) Pemakai adalah orang yang mengkonsumsi atau menggunakan produk atau jasa.

\section{b. Proses Pengambilan Keputusan Pembelian}

Menurut Kotler dan Keller (2007:235), keputusan pembelian merupakan proses dimana konsumen melewati lima tahap, yaitu pengenalan masalah, pencarian informasi, evaluasi alternatif, keputusan pembelian, dan perilaku pasca pembelian, yang mulai jauh sebelum pembelian aktual dilakukan dan memiliki dampak yang lama setelah itu.

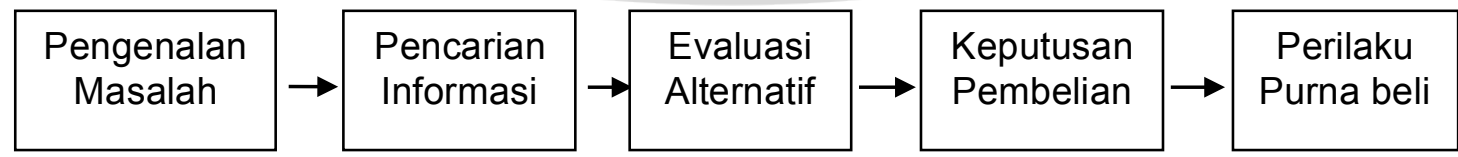

Gambar 1. Proses Keputusan Pembelian

Akhirnya secara umum proses pengambilan keputusan membeli ini dapat dikategorikan ke dalam tiga bentuk yaitu :

1) Proses pengembalian keputusan yang luas (extended decision making) 
Di sini akan banyak muncul pertimbangan karena banyak alternatif, seperti masalah merek, mutu, harga, model, kegunaan, dsb. Kategori ini biasanya muncul dalam menentukan pembelian barang yang mahal dan jarang dibeli, seperti membeli mobil, dan barang-barang elektronik keperluan rumah tangga.

2) Pengambilan keputusan terbatas (limited decision making)

Dalam hal ini konsumen telah mengenal masalahnya, kemudian mengevaluasi hanya beberapa alternative produk, merek, harga.

3) Proses pengambilan keputusan yang bersifat rutin atau kebiasaan (habitual decision making) Proses ini sangat sederhana, konsumen telah mengenal masalahnya, dan sudah jelas pula merek yang akan ia beli, dimana membeli, keputusan cepat bisa diambil.

\section{Hipotesis}

$\mathrm{H}_{\mathrm{a}}$ : Terdapat hubungan strategi harga terhadap keputusan pembelian di Toko KAKIKU

Biak

$\mathrm{H}_{0}$ : Tidak ada hubungan strategi harga terhadap keputusan pembelian di Toko KAKIKU

Biak

\section{METODE PENELITIAN}

\section{A. Lokasi dan Jenis Penelitian}

Lokasi penelitian dilakukan pada toko KAKIKU yang beralamat di Jalan Bosnik Raya, Biak Numfor. Penelitian ini menggunakan jenis penelitian kuantitatif. Pendekatan penelitian kuantitatif sebagaimana dikemukakan oleh Sugiyono (2010:13) yang dapat diartikan sebagai metode yang berlandaskan pada filsafat positivisme, digunakan untuk meneliti pada populasi atau sampel tertentu, teknik pengambilan sampel pada umumnya dilakukan random, pengumpulan data menggunakan instrumen penelitian, analisis data bersifat kuantitatif/statistik dengan tujuan untuk menguji hipotesis yang telah ditetapkan.

\section{B. Populasi, Sampel dan Teknik Pengambilan Sampel}

Dalam penelitian ini populasi yang diambil adalah konsumen KAKIKU selama Bulan Juli hingga Desember 2019 sebanyak 50 orang. Maknanya sampel yang diambil dapat mewakili atau representatif bagi populasi tersebut (Sugiyono, 2010:118). Dalam menentukan jumlah sampel ini peneliti menggunakan rumus Slovin yaitu sebagai berikut:

$$
n=\frac{N}{1+N(e)^{2}}
$$

Dimana :

$\mathrm{n}=$ Ukuran sampel

$\mathrm{N}=$ Jumlah populasi

e = Posisi yang ditetapkan (5\%)

Berdasarkan rumus tersebut maka jumlah sampel yang diteliti yaitu:

$$
\begin{gathered}
n=\frac{N}{1+N(e)^{2}} \\
n=\frac{50}{1+50(0.05)^{2}} \\
n=44.44 \text { dibulatkan menjadi } 44
\end{gathered}
$$

Sehingga sampel yang digunakan dalam penelitian ini berjumlah 44 orang/responden. 


\section{HASIL DAN PEMBAHASAN}

\section{A. Deskripsi Responden}

Dari hasil penelitian yang dilakukan dengan penyebaran kuesioner kepada konsumen yang telah membeli di toko KAKIKU sebanyak 44 responden. Dari hasil penyebaran kuesioner tersebut diperoleh data responden seperti jenis kelamin, tingkat usia/umur, pendidikan, dan jenis pekerjaan. Penjelasan untuk masing-masing data sebagai berikut :

\section{Jenis Kelamin Pengunjung Toko KAKIKU}

Tabel 2. Jenis Kelamin Pengunjung Toko KAKIKU

\begin{tabular}{|c|l|c|c|}
\hline No. & Jenis Kelamin & Jumlah & Presentase \\
\hline 1 & Laki-Laki & 25 & $56,82 \%$ \\
\hline 2 & Perempuan & 19 & $43,18 \%$ \\
\hline \multicolumn{2}{|c|}{ Total } & 44 & $100 \%$ \\
\hline
\end{tabular}

Sumber data : Diolah, 2020

Berdasarkan hasil penelitian menunjukkan bahwa responden berdasarkan jenis kelamin dibagi menjadi laki-laki dan perempuan. Dari 44 responden yang berjenis kelamin laki-laki sebanyak 25 atau 56,82\%, sedangkan responden yang berjenis kelamin perempuan sebanyak 19 atau 43,18\%. Pada kategori jenis kelamin didominasi oleh responden dengan jenis kelamin laki-laki.

\section{Tingkat Usia Pengunjung Toko KAKIKU}

Tabel 3. Tingkat Usia Pengunjung Toko KAKIKU

\begin{tabular}{|c|l|c|c|}
\hline No. & Tingkat Usia & Jumlah & Presentase \\
\hline 1 & $<20$ Tahun & 9 & $20,45 \%$ \\
\hline 2 & $20-29$ Tahun & 21 & $47,73 \%$ \\
\hline 3 & $30-39$ Tahun & 8 & $18,18 \%$ \\
\hline 4 & $>39$ Tahun & 6 & $13,64 \%$ \\
\hline \multicolumn{2}{|c|}{ Total } & 44 & $100 \%$ \\
\hline
\end{tabular}

Sumber data : Diolah, 2020

Berdasarkan hasil penelitian meunjukkan bahwa responden berdasarkan tingkat usia ternyata responden yang paling banyak adalah responden usia 20 - 29 sebanyak 21 responden atau 47,73\%. Untuk usia dibawah 20 tahun sebanyak 9 responden atau 20,45\%,usia 30 - 39 tahun sebanyak 8 responden atau $18,18 \%$ dan usia diatas 39 tahun sebanyak 6 responden atau $13,64 \%$.

\section{Tingkat Pendidikan Pengunjung Toko KAKIKU}

Tabel 4. Tingkat Pendidikan Pengunjung Toko KAKIKU

\begin{tabular}{|c|l|c|c|}
\hline No. & Tingkat Pendidikan & Jumlah & Presentase \\
\hline 1 & SMP & 1 & $2,27 \%$ \\
\hline 2 & SMA & 26 & $59,09 \%$ \\
\hline 3 & Diploma & 2 & $4,54 \%$ \\
\hline 4 & S1 & 15 & $34,09 \%$ \\
\hline 5 & S2 & 0 & 0 \\
\hline 6 & S3 Total & 0 & 0 \\
\hline \multicolumn{2}{|c|}{ T } & 44 & $100 \%$ \\
\hline
\end{tabular}

Sumber data : Diolah, 2020 
Berdasarkan hasil penelitian menunjukkan bahwa dari 44 responden untuk responden dengan pendidikan jenjang SMP sebanyak 1 responden atau 2,27\%, SMA sebanyak 26 responden atau 59,09\%, diploma sebanyak 2 responden atau 4,54\%, S1 sebanyak 15 responden atau 34,09\%. Untuk S2 dan S3 sebanyak 0 responden.

\section{Jenis Pekerjaan Pengunjung Toko KAKIKU}

Tabel 5. Jenis Pekerjaan Pengunjung Toko KAKIKU

\begin{tabular}{|c|l|c|c|}
\hline No. & \multicolumn{1}{|c|}{ Jenis Pekerjaan } & Jumlah & Presentase \\
\hline 1 & PNS & 6 & $13,64 \%$ \\
\hline 2 & Wiraswasta & 14 & $31,82 \%$ \\
\hline 3 & Mahasiswa/Pelajar & 11 & $25 \%$ \\
\hline 4 & Lainnya & 13 & $29,54 \%$ \\
\hline \multicolumn{2}{|c|}{ Total } & 44 & $100 \%$ \\
\hline
\end{tabular}

Sumber data : Diolah, 2020

Berdasarkan hasil penelitian menunjukkan bahwa dari 44 responden ternyata yang pekerjaannya sebagai PNS sebanyak 6 responden atau 13,64\%, yang pekerjaannya sebagai wiraswasta sebanyak 14 responden atau 31,82\%, yang pekerjaannya sebagai mahasiswa/pelajar sebanyak 11 responden atau $25 \%$, dan yang memiliki pekerjaan lainnya yaitu sebanyak 13 responden atau $29,54 \%$.

\section{B. Analisis Data dan Pengujian Hipotesis}

\section{Hasil Uji Instrumen Penelitian}

Uji instrumen data dalam penelitian ini dilakukan untuk menguji kuesioner yang digunakan agar seakurat mungkin dan dapat dipertanggungjawabkan. Uji ini dilakukan untuk menguji apakah sebuah instrumen itu baik atau tidak. Adapun uji instrumen yang digunakan dalam penelitian ini yaitu uji validitas, uji reliabilitas, dan uji normalitas.

\section{a. Uji Validitas}

Pengujian validitas dilakukan pada dua variabel dalam penelitian ini yaitu strategi harga dan keputusan pembelian konsumen. Teknik yang digunakan yaitu melakukan korelasi bivariate antara masing-masing skor indikator dengan total skor konstruk. Teknik ini membandingkan nilai $r_{\text {hitung }}$ dengan $r_{\text {tabel, }}$, $r_{\text {tabel }}$ dicari pada signifikansi 0,05 dan jumlah data $(n)=44, d f=n-2$ maka didapat $r_{\text {tabel }}$ sebesar 0,297 . Apabila nilai $r_{\text {hitung }}>r_{\text {tabel }}$, berarti pernyataan tersebut valid dan apabila nilai $r_{\text {hitung }}<r_{\text {tabele }}$, berarti pernyataan tersebut tidak valid Tabel 6. Hasil Uji Validitas

\begin{tabular}{|c|c|c|c|c|}
\hline Variabel & Pernyataan & $\mathbf{r}_{\text {hitung }}$ & $\mathbf{r}_{\text {tabel }}$ & Keterangan \\
\hline \multirow{3}{*}{$\begin{array}{c}\text { Strategi } \\
\text { Harga }\end{array}$} & X.1 & 0,653 & 0,297 & Valid \\
\cline { 2 - 5 } & X.2 & 0,611 & 0,297 & Valid \\
\cline { 2 - 5 } & X.3 & 0,742 & 0,297 & Valid \\
\cline { 2 - 5 } & X.4 & 0,612 & 0,297 & Valid \\
\hline \multirow{3}{*}{$\begin{array}{c}\text { Keputusan } \\
\text { Pembelian } \\
\text { Konsumen }\end{array}$} & Y.1 & 0,744 & 0,297 & Valid \\
\cline { 2 - 5 } & Y.2 & 0,615 & 0,297 & Valid \\
\cline { 2 - 5 } & Y.3 & 0,455 & 0,297 & Valid \\
\cline { 2 - 5 } & Y.4 & 0,322 & 0,297 & Valid \\
\cline { 2 - 5 } & 0,606 & 0,297 & Valid \\
\hline
\end{tabular}

Sumber data : Diolah, 2020

Berdasarkan hasil analisis dari uji validitas di atas diketahui bahwa semua variabel nilai $r_{\text {hitung }}>r_{\text {tabel, }}$, hal ini menunjukkan bahwa pernyataan mampu mengukur variabel strategi harga dan keputusan pembelian konsumen. 


\section{b. Uji Reabilitas}

Uji reliabilitas dilakukan untuk mengetahui konsistensi jawaban responden dalam menjawab pernyataanpernyataan yang mengukur variabel strategi harga dan keputusan pembelian konsumen. Uji reliabilitas dalam penelitian ini menggunakan SPSS 22.0, yang memberikan fasilitas untuk mengukur reliabilitas dengan uji statistik Split-Half Spearman Brown. Indikator atau item pernyataan dapat dikatakan reliabel apabila nilai dari Split-Half $>0,60$. Hasil keseluruhan dari uji reliabilitas dapat dilihat dalam tabel berikut ini:

Tabel 7. Hasil Uji Reabilitas

\begin{tabular}{|c|c|c|c|}
\hline Variabel & $\begin{array}{c}\text { Nilai Split-Half } \\
\text { Spearman Brown }\end{array}$ & $\begin{array}{c}\text { Standar } \\
\text { Realiabel }\end{array}$ & Keterangan \\
\hline Strategi Harga & 0,557 & 0,60 & Sedang \\
\hline $\begin{array}{c}\text { Keputusan Pembelian } \\
\text { Konsumen }\end{array}$ & 0,420 & 0,60 & Sedang \\
\hline
\end{tabular}

Sumber data : Diolah, 2020

Hasil uji reliabilitas di atas menunjukkan bahwa kedua variabel mempunyai nilai Split-Half< 0,60, sehingga dapat disimpulkan bahwa indikator yang digunakan pada variabel strategi harga dan keputusan pembelian konsumen dinyatakan sedang atau cukup dapat dipercaya sebagai alat ukur.

\section{c. Uji Normalitas}

Uji normalitas bertujuan untuk menguji apakah model regresi, variabel pengganggu atau residual mempunyai distribusi normal. Uji normalitas dapat dilakukan dengan melihat Asymp.Sig.(2-tailed) pada hasil uji dengan dengan menggunakan one sample kolmogorov-smirnov test (K-S). Data bisa dikatakan terdistribusi normal jika nilai Asymp.Sig.(2-tailed) $>0,05$. Berikut ini adalah hasil perhitungan uji normalitas dari variabel strategi harga dan keputusan pembelian konsumen yang diperoleh dapat dilihat pada tabel berikut ini:

Tabel 8. Hasil Uji Normalitas

\begin{tabular}{|c|c|c|}
\hline \multicolumn{3}{|c|}{ One-Sample Kolmogorov-Smirnov Test } \\
\hline & & $\begin{array}{l}\text { Unstandardized } \\
\text { Residual }\end{array}$ \\
\hline $\mathrm{N}$ & & 44 \\
\hline Normal Parameters ${ }^{a, b}$ & Mean &, 0000000 \\
\hline & Std. Deviation & 2,51065062 \\
\hline Most Extreme Differences & Absolute & , 101 \\
\hline & Positive &, 066 \\
\hline & Negative &,- 101 \\
\hline Test Statistic & & ,101 \\
\hline Asymp. Sig. (2-tailed) & &, $200^{c, d}$ \\
\hline \multicolumn{3}{|c|}{ a. Test distribution is Normal. } \\
\hline \multicolumn{3}{|l|}{ b. Calculated from data. } \\
\hline \multicolumn{3}{|c|}{ c. Lilliefors Significance Correction. } \\
\hline \multicolumn{3}{|c|}{ d. This is a lower bound of the true significance. } \\
\hline \multicolumn{3}{|c|}{ Sumber data : Diolah, 2020} \\
\hline
\end{tabular}

Dari tabel di atas dapat diketahui bahwa besarnya nilai Asymp.Sig.(2-tailed) adalah 0,200. Hal tersebut menunjukkan bahwa nilai Asymp. Sig.(2-tailed) $>0,05$ yaitu 0,200 $>0,05$. Sehingga dapat disimpulkan bahwa data residual telah terdistribusi secara normal. 


\section{Hasil Analisis Data}

a. Hubungan Strategi Harga Terhadap Keputusan Pembelian Konsumen di Toko KAKIKU Biak

Untuk mengetahui hubungan strategi harga terhadap keputusan pembelian konsumen, maka analisis data yang digunakan dalam penelitian ini adalah uji koefisien korelasi. Uji koefisien korelasi bertujuan untuk mengukur seberapa besarnya hubungan antar dua variabel.

Koefisien korelasi biasa dilambangkan dengan huruf $r$ dimana nilai $r$ dapat bervariasi dari -1 sampai +1 . Nilai $r$ yang mendekati -1 atau +1 menunjukkan hubungan yang kuat antara dua variabel tersebut dan nilai $r$ yang mendekati 0 mengindikasikan lemahnya hubungan antara dua variabel tersebut. Sedangkan tanda + (positif) menunjukkan kedua variabel tersebut memiliki hubungan yang searah, dan tanda - (negatif) memiliki hubungan yang berlawanan. Hasil uji koefisien korelasi dapat dilihat pada tabel berikut ini :

Tabel 9. Hasil Uji Koefisien Korelasi

Correlations

\begin{tabular}{|c|c|c|c|}
\hline & & Strategi Harga & $\begin{array}{l}\text { Keputusan Pembelian } \\
\text { Konsumen }\end{array}$ \\
\hline \multirow[t]{3}{*}{ Strategi Harga } & Pearson Correlation & 1 &, $521^{* *}$ \\
\hline & Sig. (2-tailed) & &, 000 \\
\hline & $\mathrm{N}$ & 44 & 44 \\
\hline \multirow[t]{3}{*}{ Keputusan Pembelian Konsumen } & Pearson Correlation &, $521^{* \star}$ & 1 \\
\hline & Sig. (2-tailed) &, 000 & \\
\hline & $\mathrm{N}$ & 44 & 44 \\
\hline
\end{tabular}

**. Correlation is significant at the 0.01 level (2-tailed).

Sumber data : Diolah, 2020

Dari tabel di atas dapat diketahui bahwa hasil uji koefisien korelasi diperoleh nilai $r_{\text {hitung }}$ sebesar 0,521 dengan signifikansi sebesar 0,000 . Hal ini berarti $r_{\text {hitung }}>r_{\text {tabel }}(0,521>0,297)$ dengan signifikan $0,000<0,05$, maka dapat disimpulkan bahwa variabel strategi harga mempunyai hubungan yang signifikan terhadap keputusan pembelian konsumen.

\section{b. Sumbangan Strategi Harga Terhadap Keputusan Pembelian Konsumen di Toko KAKIKU Biak}

Untuk mengetahui sumbangan strategi harga terhadap keputusan pembelian konsumen, maka analisis data yang digunakan dalam penelitian ini adalah uji koefisien determinasi. Uji koefisien determinasi bertujuan untuk mengukur seberapa jauh kemampuan model dalam menerapkan variasi variabel dependen. Nilai koefisien determinasi adalah antara angka nol dan satu. Jika nilai $R^{2}$ kecil, maka kemampuan variabel-variabel independen akan terbatas. Nilai $R^{2}$ yang mendekati satu berarti variabel independen memberikan hampir semua informasi yang dibutuhkan untuk menjelaskan variabel dependen. Hasil uji koefisien determinasi $\left(R^{2}\right)$ dapat dilihat pada tabel berikut ini :

Tabel 10. Hasil Uji Koefisien Determinasi

Model Summary

\begin{tabular}{|l|r|r|r|r|}
\hline Model & $\mathrm{R}$ & R Square & Adjusted R Square & $\begin{array}{c}\text { Std. Error of the } \\
\text { Estimate }\end{array}$ \\
\hline 1 &, $521^{\mathrm{a}}$ &, 272 &, 255 & 2,54036 \\
\hline
\end{tabular}

a. Predictors: (Constant), Strategi Harga

Sumber data : Diolah, 2020

Dari tabel di atas dapat diketahui besarnya nilai $r$ square adalah 0,272 . Hal ini berarti variasi variabel keputusan pembelian konsumen dapat dijelaskan oleh variabel strategi harga sebesar $27,2 \%$ dan $72,8 \%(100 \%-27,2 \%=$ $72,8 \%$ ) dijelaskan oleh faktor-faktor lain yang tidak disertakan dalam penelitian ini. 
c. Hubungan Signifikan Strategi Harga Terhadap Pembelian Konsumen di Toko KAKIKU Biak

Untuk mengetahui hubungan yang signifikan strategi harga terhadap keputusan pembelian, maka analisi data yang digunakan dalam penelitian ini adalah regresi linear sederhana dan uji t.

1) Analisis regresi linier sederhana digunakan untuk mengukur besarnya pengaruh satu variabel independen (strategi harga) terhadap variabel dependen (keputusan pembelian konsumen). Hasil analisis regresi linier sederhana dapat dilihat pada tabel berikut ini:

Tabel 11. Regresi Linier Sederhana

Coefficients $^{a}$

\begin{tabular}{|c|c|c|c|c|c|}
\hline \multirow{2}{*}{ Model } & \multicolumn{2}{|c|}{ Unstandardized Coefficients } & \multirow{2}{*}{$\begin{array}{c}\text { Standardized } \\
\text { Coefficients }\end{array}$} & \multirow{2}{*}{ T } & \multirow{2}{*}{ Sig. } \\
\cline { 2 - 5 } & B & Std. Error & Beta & & \multirow{2}{*}{, 012} \\
\hline (Constant) & 7,498 & 2,867 & &, 615 &, 000 \\
\hline
\end{tabular}

a. Dependent Variable: Keputusan Pembelian Konsumen

Sumber data : Diolah, 2020

Berdasarkan pada tabel 11 di atas, persamaan regresi linier sederhana adalah sebagai berikut:

$$
\begin{aligned}
& Y=a+b X \\
& Y=7,498+0,728 X
\end{aligned}
$$

Dari hasil persamaan regresi linier sederhana di atas maka dapat diinterprestasikan sebagai berikut :

a) Konstanta sebesar 7,498, artinya jika variabel independen (strategi harga) dianggap konstan, maka tingkat keputusan pembelian konsumen sebesar 7,498.

b) Koefisien regresi strategi harga (X) sebesar 0,728 , artinya jika strategi harga ditingkatkan 1 satuan, maka akan meningkatkan keputusan pembelian konsumen sebesar 0,728.

2) Uji t

Uji t menunjukkan seberapa jauh pengaruh variabel independen dalam menerangkan variabel dependen. Hasil uji $t$ bisa dilihat dari tabel coefficients pada kolom sig. dapat dikatakan terdapat pengaruh antarah variabel bebas dengan variabel terikat secara parsial apabila probilitas nilai $t$ atau signifikansinya $<0,05$. Hasil dari uji t dapat dilihat dalam tabel berikut ini :

Tabel 12. Uji t

Coefficients $^{\mathrm{a}}$

\begin{tabular}{|c|c|c|c|c|c|}
\hline \multirow{2}{*}{ Model } & \multicolumn{2}{|c|}{$\begin{array}{c}\text { Unstandardized } \\
\text { Coefficients }\end{array}$} & $\begin{array}{c}\text { Standardized } \\
\text { Coefficients }\end{array}$ & \multirow{2}{*}{ T } & Sig. \\
\cline { 2 - 4 } & $\mathrm{B}$ & Std. Error & Beta & & \multirow{2}{*}{, 012} \\
\hline (Constant) & 7,498 & 2,867 & & 2,615 &, 000 \\
\hline Strategi Harga &, 728 &, 184 &, 521 & 3,960 & \\
\hline
\end{tabular}

Sumber data : Diolah, 2020

a. Dependent Variable: Keputusan Pembelian Konsumen

Berdasarkan tabel 12 mengenai hasil uji $\mathrm{t}$ di atas dapat diketahui hasil thitung variabel strategi harga sebesar 3,960 dengan probilitas sebesar 0,000. Untuk mengetahui tabel dapat dicari dengan menggunakan Microsoft Excel dengan rumus $=\operatorname{tinv}(\alpha ; d f 2)$ dan nilai tabel diperoleh 2,015. Sehingga dapat diperoleh hasil 3,960 > 2,015 dengan signifikansi sebesar 0,000 $<0,05$, maka dapat disimpulkan bahwa variabel strategi harga berpengaruh terhadap keputusan pembelian konsumen. Hal ini berarti semakin tinggi strategi harga, maka semakin tinggi pula keputusan pembelian konsumen. Strategi harga 
berpengaruh signifikan terhadap keputusan pembelian konsumen di Toko KAKIKU Biak. Hal ini dinyatakan berdasarkan uji $t$, strategi harga berpengaruh signifikan terhadap keputusan pembelian konsumen dengan nilai $t_{\text {hitung }}>t_{\text {tabel }}$ sebesar 3,960 $>2,015$ dengan signifikansi sebesar $0,000<0,05\left(\mathrm{H}_{a}\right.$ diterima dan $\mathrm{H}_{0}$ ditolak). Dalam penelitian ini, variabel strategi harga dengan indikator keterjangkauan harga, kesesuaian harga dengan kualitas, daya saing harga dan kesesuaian harga dengan kualitas mempengaruhi keputusan pembelian konsumen.

Hal ini menyatakan bahwa Toko KAKIKU Biak dengan memperhatikan strategi penjualan mengenai harga seperti keterjangkauan harga, kesesuaian harga dengan kualitas, daya saing harga dan kesesuaian harga dengan manfaat maka akan semakin tinggi pula dalam menentukan keputusan pembelian konsumen. Sebab konsumen dapat menentukan pembelian suatu produk yang sesuai dengan kebutuhan dan keinginannya. Sehingga strategi penjualan dari segi harga di Toko KAKIKU Biak telah dilakukan dengan baik.

\section{PENUTUP}

\section{A. Simpulan}

Beberapa kesimpulan dari penelitian ini dapat dijelaskan sebagai berikut:

1. Hasil uji koefisien korelasi disimpulkan bahwa variabel strategi harga memiliki hubungan terhadap keputusan pembelian di Toko KAKIKU Biak sebesar 0,521.

2. Hasil uji koefisien determinasi disimpulkan bahwa strategi harga memberikan sumbangan terhadap keputusan pembelian di Toko KAKIKU Biak sebesar 0,272 atau 27,2\% dan sisanya ditentukan oleh variabel lain yang tidak disertakan dalam penelitian ini.

3. Berdasarkan analisis regresi linier sederhana dapat disimpulkan strategi harga berpengaruh signifikan terhadap keputusan pembelian konsumen Toko KAKIKU Biak ( $\mathrm{H}_{\mathrm{a}}$ diterima dan $\mathrm{H}_{0}$ ditolak).

\section{B. Saran}

Berdasarkan kesimpulan di atas, maka penulis memberikan saran dalam penelitian ini antara lain:

1. Dalam produk sepatu dan sandal hendaknya lebih memperhatikan strategi harga terhadap keputusan pembelian konsumen karena dengan memperhatikan hal tersebut akan berpengaruh pada keputusan pembelian sepatu dan sandal di Toko KAKIKU

2. Dalam penelitian ini penulis hanya membahas satu variabel yang dijadikan faktor keputusan pembelian konsumen. Bagi peneliti selanjutnya hendaknya mampu menambahkan variabel lain sehingga dapat mengetahui faktor lain yang mempengaruhi keputusan pembelian konsumen di Biak Numfor.

\section{DAFTAR PUSTAKA}

[1]. Alma, Buchari (2004), Manajemen Pemasaran dan Pemasaran Jasa, CV. Alfa Beta, Bandung.

[2]. Engel, James F (1994), Perilaku Konsumen, Ed. 6, Jilid 1, Binarupa Aksara, Jakarta Barat..

[3]. Kotler, Philip dan Keller (2007), Manajemen Pemasaran, Ed.12, Jilid 1, PT. Indeks, Jakarta.

[4]. Kotler, Philip dan Gary Amstrong (2012), Principles of Marketing, Prentice Hall, New Jersey.

[5].

(2015), Marketing an Introducing Prentice Hall Twelf Edition, Pearson Education Inc, England.

[6]. Sugiono (2010), Metode Penelitian Kuantitatif, dan R\&D, CV. Alfabeta, Bandung.

[7]. Sumarni, Murti dan John Soeprihanto (2010), Pengantar Bisnis (Dasar-Dasar Ekonomi Perusahaan), Ed. 5, Liberty Yogyakarta, Yogyakarta.

[8]. Tjiptono, Fandy (2002), Strategi Pemasaran, Penerbit Andi, Yogyakarta.

[9]. (2008), Strategi Pemasaran, Ed. 3, CV. Andi Offset, Yogyakarta.

[10]. (2009), Strategi Pemasaran, Ed. 2, Cetakan 7, Andi Offset, Yogyakarta. 